\title{
Factors Affecting Delaying and Accelerating Efforts of Student Study Completion
}

\author{
Ifmalinda ${ }^{1}$, Feri Arlius ${ }^{2}$ \\ \{ifmalinda@ae.unand.ac.id $\left.{ }^{1}\right\}$ \\ ${ }^{1,2}$ Agricultural Engineering Department, Faculty of Agricultural Technology, Universitas Andalas, \\ Padang, Indonesia
}

\begin{abstract}
Ideally, under graduate student complete their study within 4 years. However, it is found that many students complete their degree more than 4 years. There are a lot of factors that causing the delay in study completion of the student. Faculty of Agricultural Technology students consist of thousands students who stuying now, they will complete in different time each others. Aims of this study are (1) to find out the internal and external factors that hamper the student to complete their degree within time, (2) Effort to solve the student overtime study. This research is using survey approchment.Samples were taken by using proportional random sampling method. Research results show that the factors causing the delay of the student completion study are factor internal with score $75.94 \%$ and external factor $73.028 \%$. Meanwhile, efforts to accelerate the student study completion can be done by giving inputs toward lecturers, students, and campus side. Lecturers are expected to give extra time to discusswith the students, motivation and simplifying the time to discuss with the students.
\end{abstract}

Keywords: Delay on study, students, Agricultural technology, acceleration, Study completion.

\section{Introduction}

One of way to build the character of country is campus. Concomitant swiftly global challenge, in the education side of challenge is also huge. This case push the students to reach the best achievement. To reach the best achivement needs the proper program and good education practices. The success of the education process is the contribution from all stakeholders, i.e educators, learners, curricullum, facilities and infrastructure, time, cost and other components.

According to Siagian (2006), education is the whole process of technique and methode of education in order to transfer the knowledge from one person to another in accordance with stipulated standard and procedure. Sedarmayanti (2001) expressed that trough the education, the one is prepared to be ready to know, recognize and develop the thinking methode in systematic way so that able to solve the problem that will be faced in their life of future.

Faculty of Agricultural Technology students consist of thousands students who stuying now, they will complete in different time each others. One batch of student can complete difference time depend on the student itself. In fatc, the most of student still complete their study overtime or more than 4 years. The department officer always check the student who do not have the possibility to complete their study every three months. The student who complete their degree more than study duration treshold will be dropped out from the university. 
Many factors that cause the delay of study completion of student. Several efforts have been done by department to accelerate the study time. Based on those facts, the writer want to do the research entitled "Factors affecting delay and accelerating efforts os student study completion in Faculty of Agricultural Technology, Universitas Andalas.

Aims of this study are (1) To find out the internal and external factors that hamper the student to complete their degree within time, (2) To find out External factors that hamper the student to complete their degree within time, (3) Efforts to solve the student overtime study.

\section{Research Method}

This reseacrh used survey approachment. The samples were taken by using proportional random sampling i.e. using balanced representative samples. If the population is more than 100, then, sample will be taken $10-15 \%$ or $20-25 \%$. Samples were taken randomly and balance. Sample were taken from batch 2012 until 2015. Number of sample consists of 23 student from department of Agricultural Engineering and 37 students from department of Agricultural Product Technology.

Table 1. Number of student from Agricultural Engineering and Agricultural Products Technology.

\begin{tabular}{ccccccc}
\hline Batch & \multicolumn{2}{c}{ Number } & \multicolumn{2}{c}{$\mathbf{2 0 \%}$ from Total } & \multicolumn{2}{c}{ Round Up } \\
\hline & $\begin{array}{l}\text { Agricultural } \\
\text { Enginering }\end{array}$ & $\begin{array}{l}\text { Agricultural } \\
\text { Products } \\
\text { Technology. }\end{array}$ & $\begin{array}{l}\text { Agricultural } \\
\text { Enginering }\end{array}$ & $\begin{array}{l}\text { Agricultural } \\
\text { Products } \\
\text { Technology }\end{array}$ & $\begin{array}{l}\text { Agricultural } \\
\text { Enginering }\end{array}$ & $\begin{array}{l}\text { Agricultural } \\
\text { Products } \\
\text { Technology. }\end{array}$ \\
\hline 2012 & 26 & 4 & 5,2 & 0,8 & 5 & 1 \\
2013 & 9 & 26 & 1,8 & 5,2 & 2 & 5 \\
2014 & 17 & 44 & 3,4 & 8,8 & 4 & 9 \\
2015 & 62 & 107 & 12,4 & 21,4 & 12 & 22 \\
\hline
\end{tabular}

\section{Data Collection Methods}

Data collection was taken by using questionaries. The questionaries were distributed to repondent with expectation to gain the answer of the questions. The answer consists of three categories i.e. often (3), rare (2) and, never (1).

\section{Data analysis methods}

After necessary data collected, then data were clasified and analysed by using descriptive quantitative, where data have been taken, obtained,arranged, and given an explanation. Result of analysis was classified according to respondent presentation and can be a benchmark in decision making.

Steps of data collection:

a. Internal factors that affect toward delaying of student on their study completion are physical factor ( body health condition etc) and physicological factors for example mental condition, unconfident, pressure etc, and other factors like fatigue, time management, and laziness to do the asignentment.

b. .b.External factor that affect toward delaying of student on their study completion are; family ( the way of his/her parent to educate them, family economy, family status, 
University factor ( education method, curricullum, student and lecturer relation, lecture time, and infrastructures).

c. Determine the amount of percentage of alternative answer of respondent by using equation below:

d. $\quad \mathrm{P}=(\mathrm{F} / \mathrm{N}) \times 100 \%$

e. Memberikan penjelasan dan menarik kesimpulan

f. Giving the explanation and withdraw the conclusion

\section{Results and Discussion}

\section{Internal Factors}

Factor internal is the factor that coming from inside that affect of delaying student study completion in Faculty of Agricultural Technology, Universitas Andalas. The internal factor that cause the delaying student study completion in faculty of agricultural technology, University of Andalas are phisical factors ; body health condition, phisicological factors, mental condition, unconfident, pressure etc, and other factors like fatigue, time management, and laziness to do the assignment.

Number of all the alternative answer for internal factor in 10 items questionnaire statement is 600 . Option of " $\mathrm{S}$ " is 269 , option of" $\mathrm{J}$ " is 229 , and option of'TP" is 102 . Internal factor become the factor that caused the student delay on their study completion in Faculty of Agricultural Technology, Andalas University. It can be seen on the Figure 1.

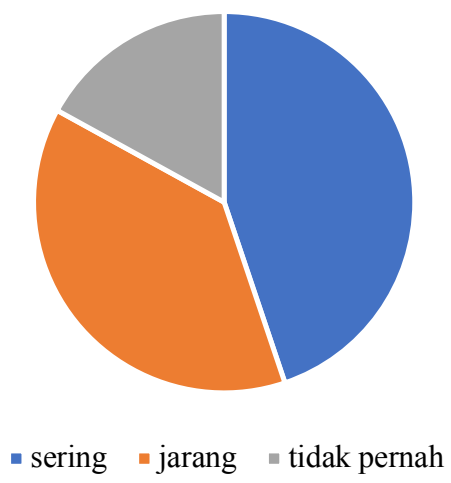

Fig. 1. Internal factor diagram that become the factor that cause the student study completion in Faculty of Agricultural Technology, Universitas Andalas

Each of total of answer options were multiplied by quality of each options, where option of "S" has the quality 3, option of "J" has the quality 2, option of "TP" has the quality 1 ,

For alternative "S", Respondents chose For alternative "J", Respondents chose For alternative "TP", Respondents chose So that the total can be obtained

$$
\begin{aligned}
& 269 \times 3=807 \\
& 229 \times 2=458 \\
& 102 \times 1=102 \\
& 600(\mathrm{~N})=1367(\mathrm{~F})
\end{aligned}
$$


Score $600(\mathrm{~N})$ nust be multiplied by 3 because option of the answer are 3 options i.e S,J, and TP, after multiplied, the result is 1800 , After known the quantity of F and $\mathrm{N}$, then sibstitude into below formula:

$$
\begin{aligned}
\mathrm{P} & =\frac{F}{N} \times 100 \% \\
\mathrm{P} & =\frac{1367}{1800} \times 100 \% \\
& =75,944 \%
\end{aligned}
$$

Meaning od the score of $75,94 \%$, refered to the point that has been determined before. i.e. : a. $\geq 66,7 \%$ categorized as "affecting" b. $<66,7 \%$ categorized as " not affecting". Score that been obtained was $75,94 \%$. It can be concluded that there are internal factor that affect to the student study completioninfaculty of Agricultural Technology, University of Andalas.

\section{External Factors}

External factors become the reason of the delaying of student study completion in Faculty of Agricultural Technology, Universitas Andalas i.e. family factor for instance ; the way of family educated the student, family economy condition, family status, etc. University factor for example; teaching method, curriculum, lecture and student relation, university policy, infrastructure, lecture time, organisation, OGPA etc. Community factors, for instance community activities, mass media, friends, job, social status etc.

Total of the alternative answer for external factor from 20 items of questionary statement are 1200 . The option " $\mathrm{S}$ " is 431 , option " $\mathrm{J}$ " is 567 , and option "TP" is 202 , so that, the results are obtained as follow:
a. For alternative $\mathrm{S}=431$
b. For alternative $\mathrm{J}=567$
c. For alternative TP $=202$

External factor that become reason of the delaying of the student study completion in Faculty of Agricultural Technology, Universitas Andalas as shown in Figure 2.

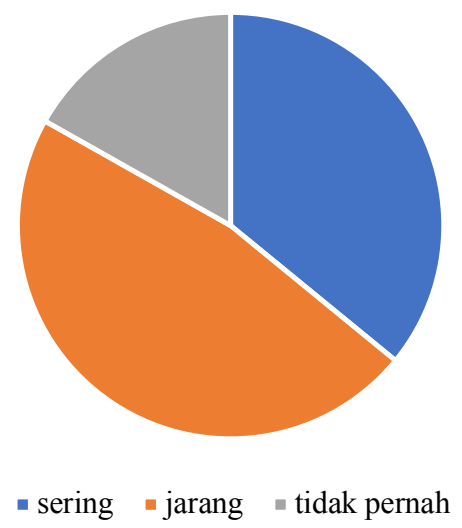

Fig. 2. External factor diagram that cause the delaying of student study completion in Faculty of Agricultural Technology, Universitas Andalas. 
Each of the option of the answer is multiplied by quality respectively, where option of $\mathrm{S}$ has the quality 3 , option of $\mathrm{J}$ has the quality 2 , option of TP has the quality 1 ,

For alternative $\mathrm{S}$, Respondent chose $431 \times 3 \quad=129$

For alternative J, Respondent chose $567 \times 2 \quad=1134$

For alternative TP, Respondent chose $202 \times 1 \quad=202$

So, the total is $1200(\mathrm{~N}) \quad=2629(\mathrm{~F})$

Score $1200(\mathrm{~N})$ have to multiplied by 3 because the answer option are three i.e S,J and $\mathrm{TP}$, after multiplied , the result is 3600 , after knowing the result of $\mathrm{F}$ and $\mathrm{N}$, then, substituded into the formula as follow:

$$
\begin{aligned}
\mathrm{P} & =\frac{F}{N} \times 100 \% \\
\mathrm{P} & =\frac{2629}{3600} \times 100 \% \\
& =73,28 \%
\end{aligned}
$$

Score that obtained is 74,028 and located from $\geq 66,7 \%$, then, it can be concluded that there are effects of external factors that cause the delaying of the student study completion in faculty of agricultural technology university of andalas.

\section{Acceleration of Study Efforts}

\section{Lecturer}

Based on the result of research collected from 60 respondents are obtained data for acceleration of study than can be done by lecturersas follows : 14 respondents (23\%) answered that the lecturer should give the spare time to the student to do discussion. 7 respondent $(11,6)$ answered that motivation should be given to students so that the student have the passion to complete their final project. 5 respondents $(8,3 \%)$ answered that easinessto do discussion to their advisors. The data obtained from rspondent for accelerating the student study completion for lecturer can be seen in the Figure 3.

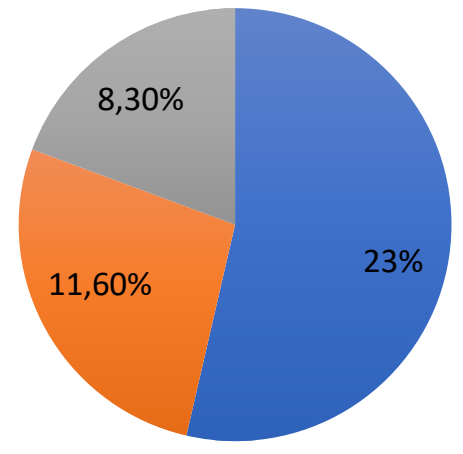

Penambahan waktu luang dosen untuk konsultasi dan bimbingan bagi mahasiswa

Agar dosen memberikan motivasi kepada mahasiswa untuk semangat dalam menyelesaikan tugas akhir

Fig. 3. Student response for lecturers in efforts to accelerateof student of Faculty of Agricultural Technology, Universitas Andalas 


\section{Student}

Efforts of acceleration of student study that reccommended for student obtained from 60 respondents were 15 respondents $(25 \%)$ answered, that student have to be active to do consultation to their advisors and active to find the books. Data obtained from respondents to accelerate the student study completion can be seen on the Figure 4.

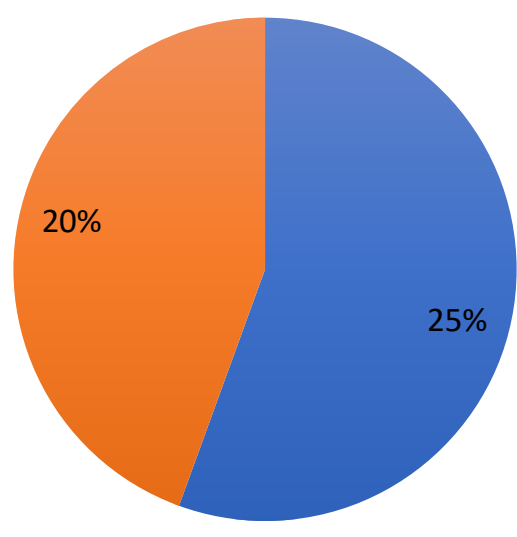

Agar mahasiswa lebih aktif melakukan bimbingan dengan dosen dan aktif mecari bahan bacaan

Agar mahasiswa menghilangkan sifat malas dalam menyelesaikan tugas kampus

Fig. 4. Student response for Student in efforts to accelerate the student study completion Faculty of Agricultural Technology, Andalas Univerity.

\section{Campus Side}

Data obtained from respondent to accelerate student study for campus side obtained from 12 respondent (12\%) answered that infrastructures of campuse have to equipped.

\section{Summary}

Factor affecting the delaying of student study of Faculty of Agricultural Technology, Universitas Andalas is influenced by internal factor; physical condition i.e health condition and physicological factor i.e mental condition, unconfidence, pressure and fatigue factor with score $75,94 \%$ and internal factore; family problem i.e. the method of education from parents, family economy, curricullum, student and lecturers relation, lecture time, and infrastructure score $73,028 \%$. The efforts of acceleration of student study can be done by contributed by lecture, student and campus side. Lecturers are expected to add the time to give extra time for discussion, for student have to be active and not to be lazy and for campus side is ecpected to provide the good infrastructure. 


\section{Recommendations}

The research about factor affecting delaying the student and effort to accelerate the student study completion in Agricultural Technology Andalas University can be learned deeply by modifying the procedure in completion of study.

\section{References}

[1] Siagian, Sondang. P. Sistem Informasi Manajemen ( Management Information System). Jakarta:PT. Bumi Aksara (2006)

[2] Supriyanto. Kumpulan Artikel Psikologi Populer. (Popular psychology Articles Collection) Jakarta: Gramedia Pustaka Utama (2003) 